\title{
Media Massa Melawan Teror: Analisis Framing pada Tajuk Koran Republika
}

\author{
Kun Wazis* \\ Universitas Padjadjaran, Bandung \\ *Email:kunwazis@gmail.com
}

\begin{abstract}
This study aims to describe the view of mass media with the Islamic ideology of Republika in response to mass shooting incident by Stephen Craig Paddock (64 years) in Las Vegas United States on Sunday (1/10/2017) which killed 59 people and injured 500 people. This research uses qualitative method with framing analysis of Robert Entman model which produces four important things. First, the editorial (beader) entitled "Irony Paddock, Irony Trump" affirms the attitude of Republika who called the Las $V$ egas tragedy an act of terror. Secondly, Republike constructed the United States president Donald Trump as a problem because of judging Paddock's brutal action as a casual shoot, not including terrorists. Thirdly, Republika rejects the double standard of Western countries, especially the US which does not mention terrorist acts because the perpetrators are not Muslim and not black. Fourthly, Republike offers a definition of terrorism as an act involving the use or attempts of sabotage, coercion, or violence that result in the death of the population in general. This research can be used as a discourse forming critical awareness in opposing the negative views of US superpower leaders who often impose the meaning of acts of terrorism with Islam and the Muslims.
\end{abstract}

Keywords : Mass Media; Terror; Framing Analysis

\begin{abstract}
ABSTRAK
Penelitian ini mendeskripsikan pandangan media massa berideologi Islam, Republika, dalam menyikapi peristiwa penembakan massal oleh Stephen Craig Paddock (64 tahun) di Las Vegas Amerika Serikat, Ahad (1/10/2017) yang menewaskan 59 orang dan melukai 500 orang. Penelitian ini menggunakan metode kualitatif dengan analisis framing model Robert Entman yang menghasilkan empat hal penting. Pertama, editorial (tajuk) berjudul "Ironi Paddock, Ironi Trump" menegaskan sikap Republika yang menyebut tragedi Las Vegas sebagai aksi teror. Kedua, Republika mengontruksikan presiden Amerika Serikat Donald Trump sebagai masalah karena menilai aksi brutal Paddock sebagai penembakan biasa, bukan termasuk teroris. Ketiga, Republika menolak standar ganda negara Barat, terutama AS yang tidak menyebut tindakan teroris karena pelakunya bukan muslim dan tidak berkulit hitam. Keempat, Republika menawarkan definisi terorisme sebagai aksi yang melibatkan penggunaan atau upaya sabotase, pemaksaan, atau kekerasan yang mengakibatkan kematian populasi secara umum. Penelitian ini dapat dijadikan wacana pembentuk kesadaran kritis dalam melawan pandangan negatif
\end{abstract}

\footnotetext{
* Tulisan ini pernah dipresentasikan di Seminar Nasional Dakwah, Bandung, 27-29 Oktober 2018
} 
pemimpin negara adidaya AS yang sering kali memaksakan makna aksi terorisme dengan Islam dan kaum muslimin.

Kata kunci: Retorika; Islam Nusantara; Media Baru.

\section{PENDAHULUAN}

Kasus penembakan yang dilakukan oleh Stephen Craig Paddock (64 tahun) di Las Vegas Amerika Serikat, pada Ahad (1/10/2017) mendapat perhatian dunia melalui berbagai pemberitaan di berbagai media massa, baik media cetak, elektronik, maupun online. Dengan demikian, dari sisi peristiwanya, tindak kriminalitas yang terjadi di negara adi daya yang dikonstruksikan media massa, menjadi menarik untuk diteliti secara ilmiah dengan beragam perspektif.

Tragedi berdarah yang menewaskan 59 orang dan melukai 500 orang itu, salah satu sikap media massa nasional yang menarik untuk diteliti adalah koran Republika dengan berbagai pertimbangan. Pertama, koran Republika mewakili media cetak mainstream berideologi Islam (Badara, 2014: 177), sehingga perspektif berita dan opini yang dikonstruksikan dapat merepresentasikan pandangan maupun sikap sebagian umat Islam di Indonesia kasus berdarah tersebut.

Berita koran Republika pada edisi Kamis 05 Oktober 2017, menempatkan peritiswa tersebut sebagai reportase yang mendalam dalam kolom "Indepth" di halaman muka, berjudul "Motif Paddock Masih Gelap", dan pada kolom Publik (halaman 9) dengan judul "Lima Motif Paddock Mencuat".

Berbeda dengan koran yang berideologi Kristen (Badara, 2014: 176), Kompas pada Edisi Kamis 05 Oktober 2017, menempatkan peristiwa brutal itu pada kolom "internasional" (halaman 8) dengan judul headline "Penembakan Dipersiapkan" dengan subjudul "Teman Perempuan Pelaku Tiba di Amerika Serikat dari Filipina".

Pandangan masyarakat yang dipilih oleh Republika pada kolom "Opini" (halaman 6) sebanyak dua artikel khusus menyikapi peristiwa tersebut, dengan menurunkan tulisan Muhammad Affan (Peminat Studi Terorisme dan Timur Tengah, bekerja di UIN Sunan Kalijaga Yogyakarta), dengan judul "Teror Zonder Teroris", dan artikel berjudul "Skizofrenia Sosial Tragedi AS" oleh Ismatillah A Nu'ad (Peneliti Indonesian Institute for Social Research and Development, Jakarta).

Berbeda dengan Kompas yang menurunkan pada kolom "Opini" (halaman 6) tiga pandangan masyarakat yang tidak terkait dengan peristiwa tersebut. Di antaranya, tulisan Fahry Ali (Salah Satu Pendiri Lembaga Studi dan Pengembangan Etika Usaha / LSPEU Indonesia) berjudul "Jokowi dan Divestasi Freeport", artikel Ari Kristianawati (Guru Sejarah SMAN Sragen) berjudul "Film dalam Nalar Edukasi", dan pendapat Syamsul Rizal berjudul "Ketika Akal Sehat Hilang" yang menyikapi persoalan pemberhentian rektor Universitas Negeri Jakarta (UNJ).

Editorial atau tajuk rencana yang merupakan suara koran secara umum (Rolnicki, Tate, Taylor, 2015: 133), yang ditulis oleh Republika pada Edisi Kamis 5 Oktober 2015 terkait atas fenomena berdarah pada kolom "Tajuk" (halaman 6) 
berjudul "Ironi Paddock, Ironi Trump" dilihat melalui sudut pandang yang kritis. Berbeda dengan Kompas yang pada tajuk rencana menurunkan sikapnya dalam rangka Hari Ulang Tahun TNI yang jatuh pada 5 Oktober, dengan judul "TNI Profesional Jadi Tantangan" dan "Menanti Fakta Terkuak" yang menyikapi sidang perkara pembunuhan Kim Jong Nam, yang salah satunya dilakukan Siti Aisyah (25) asal Indonesia. Hal ini mengindikasikan bahwa kasus Paddock di Amerika dipandang menarik dan penting disikapi hari itu, dibandingkan peristiwa lainnya di Indonesia.

Kedua, sikap redaksi dalam editorial Republika menarik, karena membangun wacana kritis dengan mengaitkan peristiwa kriminal yang dilakukan warga AS, Paddock, dengan sikap presiden Amerika Serikat Donald Trump yang disebutnya sebagai sebuah "ironi".

Opini yang dikonstruksikan oleh Republika merupakan reaksi atas sikap presiden AS yang tidak mau menyebut aksi kejam Paddock sebagai tindakan teroris, namun disebut sebagai pelaku penembakan. Dalam hal ini, Republika melakukan framing dalam opini tajuknya, dengan mempertanyakan standar ganda Trump yang tidak adil ketika pelakunya diidentifikasikan muslim, akan diberikan cap "teroris". Sedangkan terhadap warganya sendiri, Trump lebih senang mendiskusikan aksi keji penembakan itu dari sudut pandang aturan kepemilikan senjata (Republika, 2017: 6).

Ketiga, penelitian atas framing media massa Republika dengan beragam topik, khusus tema isu terorisme cukup banyak dilakukan oleh para peneliti. Penelitian Zakiyah (2015) berjudul "Agama Dalam Konstruksi Media Massa: Studi Terbadap Framing Kompas dan Republika pada Berita Terorisme” mengungkapkan dua hal pokok. Pertama, bagaimana framing Kompas dan Republika dalam mengonstruksikan peristiwa terorisme di Indonesia dalam produksi teks berita. Kedua, bagaimana agama (Islam) dikonstruksi dalam pemberitaan terorisme. Koran Kompas dan Republika mengungkapkan Islam tidak terkait dengan terorisme. Melalui pendekatan konstruktivisme dengan analisis framing, kedua media massa menyatakan ada keterkaitan teroris atau terduga teroris di Indonesia dengan jaringan teroris internasional seperti Jamaah Islamiyah dan al-Qaida.

Penelitian Zakiyah terpusat kepada berita, sedangkan yang dianalisis peneliti terfokus pada opini yang dikonstruksikan oleh dewan Redaksi Republika. Peneliti menggunakan analisis framing model Entman untuk mengungkapkan sikap (pendapat) yang diwacanakan oleh redaksi media sehingga dapat mengungkapkan pandangan utuh institusi koran Republika dalam menyikapi aksi kekerasan Paddock yang dikaitkan dengan anomali sikap presiden AS Donald Trump. Dengan demikian, akan ditemukan perspektif yang baru dalam penelitian saat ini dan didukung dengan kebaruan peristiwa "Paddock Berdarah" yang lebih aktual sebagai kasus mutakhir yang diteliti.

Penelitian Agustian (2015) berjudul "ISIS dan Terorisme dalam Wajab Media Online Indonesia"menggunakan paradigma kritis dengan analisis wacana kritis 
(AWK) model Norman Fairclough. Penelitian dengan obyek berita terorisme sejak bulan Juli-Agustus 2015 pada media siber Kompas.com dan Republika.co.id yang dikonstruksikan dalam berbagai perspektif dan adanya campur tangan dari pihak lain dalam konflik ISIS. Republika Online terkesan hati-hati dalam menyajikan pemberitaan terkait teks terorisme dalam perspektif politik dan hubungan internasional. Kompas.com cenderung labil dalam mengkonstruksi berita. Sebagai media berbasis Islam, Republika Online berupaya untuk melindungi Indonesia dari upaya pengaruh gerakan terorisme (ISIS). Republika Online juga memusatkan perhatian kepada pihak yang paling bertanggung jawab, yakni para da'i, ulama, dan imam masjid, untuk memberikan konstribusi berupa pemahaman terhadap masyarakat terkait gerakan radikal.

Republika Online merupakan media siber yang berideologi sama dengan media cetak Republika sehingga konstruksi beritanya sejalan dengan ideologi Islam. Dalam hal ini, peneliti menggunakan analisis framing model Entman dalam mengungkapkan pandangan Republika dalam tajuk secara konstruktif, bukan pendekatan kritis yang dilakukan Agustin. Hal ini ditempuh karena ideologi koran Republika maupun media online Republika sama-sama Islam, sehingga yang perlu dianalisis adalah cara pandang (sikap) redaksi Republika atas peristiwa penembakan di Las Vegas.

Penelitian Mubarok (2012) berjudul "Stigmatisasi Pemberitaan Terorisme di Media Massa" dengan paradigma kritis dan model analisis kritis model Teun Van Dijk menyebutkan bahwa pemberitaan Kompas tentang terorisme di Indonesia diturunkan dalam beberapa gagasan yang menjadi tema utama pemberitaan. Tema-tema pemberitaan tersebut adalah: keterkaitan terorisme dengan pemilu dan agama, kedudukan terorisme sebagai musuh bersama, keterlibatan pihak asing, penanganan yang tepat, dan dampak yang ditimbulkan dari aksi teror.

Penelitian Mubarok yang memilih satu media Kompas sebagai obyek yang diteliti menginspirasi peneliti untuk memfokuskan pada satu koran Republika yang diamati dengan tajuk berjudul "Ironi Paddock, Ironi Trump" sebagai upaya melahirkan penelitian yang mendalam dan baru. Hal ini salah satunya pemilihan model analisis framing yang dipilih antara Van Dijk dengan Entman yang masingmasing memiliki karakteristik khusus. Model Entman lebih tepat untuk meneliti berita politik, namun peneliti menetapkan politik redaksi dalam tajuk Republika sebagai obyek teks yang diamati.

Penelitian ini berusaha menjawab pertanyaan tentang pandangan redaksi koran Republika dalam menyikapi peristiwa berdarah di Las Vegas Amerika Serikat sebagai kajian ilmu komunikasi massa. Penelitian ini bertujuan untuk menjelaskan secara komprehensif wacana yang ditawarkan Republika kepada khalayak pembaca (konsumen, audience) melalui tajuk. Manfaat ilmiah yang diperoleh adalah wawasan mengenai subyektifitas sikap redaksi Republika dalam memandang peristiwa penembakan massal di Las Vegas. Hasil penelitian dapat dimanfaatkan sebagai bahan diskusi publik untuk menjernihkan cara pandang 
masyarakat, terutama Barat yang masih memiliki stereotip negatif terhadap umat Islam dan mengidentikkan dengan aksi terorisme.

Analisis framing masih relevan untuk mengungkapkan makna dalam konstruksi realitas teks dalam artikel tajuk yang merupakan sikap resmi redaksi Republika dan sekaligus mencerminkan ideologi Islam yang digunakan redaksi dalam menyikapi realitas penembakan Las Vegas. Hal ini sejalan dengan pandangan Mulyana (2008: 14) yang menyatakan bahwa analisis framing cocok digunakan untuk melihat konteks sosial-budaya suatu wacana, khususnya hubungan antara berita (atau wacana, tema, topik) dan ideologi, yakni proses atau mekanisme bagaimana berita membangun, mempertahankan, mereproduksi, mengubah, dan meruntuhkan ideologi.

Mengenai framing tajuk Republika terhadap peristiwa penembakan massal Las Vegas terkait erat dengan ideologi Islam yang dianut media sebagaimana dituangkan dalam visi dan misi perusahaan pers Republika. Menurut Badara (2014: 177) visi Republika adalah menjadi perusahaan media cetak terpadu skala berskala nasional serta dikelola secara profesional Islami, sehingga berpengaruh dalam proses pencerdasan bangsa, pengembangan kebudayaan, serta peningkatan keimanan dan ketakwaan dalam kehidupan masyarakat Indonesia baru. Sedangkan misi surat kabar Republika ialah: a) pencerdasan bangsa melalui pendalaman wawasan berbasis komunitas melalui pemberitaan yang akurat, aktual, terpercaya, edukatif, serta membela keadilan dan kebenaran; b) meningkatkan dan menguatkan prestasi dan dedikasi individu menjadi sebuah tim sebagai kunci untuk perkembangan perusahaan dan peningkatan kesejahteraan. Berdasarkan visi dan misi tersebut, Badara mengutip pandangan Hamad bahwa surat kabar Republika menganut ideologi pemiliknya, yakni PT Abdi Bangsa, yaitu kebangsaan, kerakyatan, dan keislaman.

Peneliti menggunakan model Robert N. Entman (dalam Eriyanto, 2009: 188-191) sebagai langkah yang dapat mengungkapkan makna realitas teks opini (tajuk) yang dikonstruksikan redaksi Republika secara lebih holistik melalui empat level sebagai berikut.

Tabel 1. Adaptasi Model Framing Entman

\begin{tabular}{ccc}
\hline Langkah & Elemen & Dimensi Yang Diamati \\
\hline 1 & Define & Bagaimana peristiwa penembakan massal Las \\
& problems(Pendefinisian & Vegas dilihat? Sebagai apa? Atau sebagai masalah \\
Masalah) & apa? \\
2 & Diganosa causes & Peristiwa "Las Vegas Berdarah" dilihat \\
& (Memperkirakan & disebabkan oleh apa? Apa yang dianggap sebagai \\
& masalah atau sumber & penyebab dari suatu masalah? Siapa (aktor) yang \\
& masalah) & dianggap sebagai penyebab masalah? \\
3 & Make moral judgement & Nilai moral apa yang disajikan untuk menjelaskan \\
& (Membuat keputusan & masalah penembakan massal tersebut? Nilai \\
& moral) &
\end{tabular}


Treatment recommendation

(Menekankan penyelesaian) moral apa yang dipakai untuk melegitimasi atau mendelegitimasi suatu tindakan?

Penyelesaian apa yang ditawarkan untuk mengatasi persoalan aksi brutal Paddock itu? Jalan apa yang ditawarkan dan harus ditempuh untuk mengatasi masalah?

Sumber: Eriyanto (2009: 188-189)

Secara ringkas, keempat langkah Entman dapat dijelaskan makna berdasarkan teks opini tajuk Republika dengan mengikuti penjelasan Abrar (2015: 16) sebagai berikut: pertama, defining problem, yaitu mendefinisikan masalah dengan pertimbangan-pertimbangan yang sering kali didasari oleh nilai-nilai kultural yang berlaku umum. Kedua, diagnosing causes, yakni mendiagnosis akar permasalahan dengan mengidentifikasi kekuatan-kekuatan yang terlibat dalam permasalahan. Ketiga, making moral judgement, yaitu memberikan penilaian moral terhadap akar permasalahan dan efek yang ditimbulkan. Keempat, suggesting remedies, yakni menawarkan solusi dengan menunjukkan perlakukan tertentu dan dugaan efek yang mungkin terjadi. Melalui keempat langkah Entman dapat diungkapkan makna sebenarnya Harian Republika dalam tajuk yang ditawarkan kepada khalayak pembacanya.

\section{HASIL DAN PEMBAHASAN}

Berdasarkan penelitian yang dilakukan terhadap teks opini pada tajuk Republika berjudul "Ironi Paddock, Ironi Trump" dapat dijelaskan hasildanpembahasan peneliti yang didasarkan pada empat level analisis framing model Entman sebagai berikut:

\section{Define Problem}

Redaksi Republika menilai tragedi penembakan massal di Las Vegas sebagai tindakan teroris, bukan penembakan biasa sebagaimana dinilai oleh presiden Amerika Serikat Donald Trump. Opini yang dikonstruksikan adalah pernyataan yang mendukung bahwa peristiwa. Pesan dalam judul tajuk "Ironi Paddcok, Ironi Trump" merupakan bahasa simbolik untuk menyatakan bahwa makna yang terjadi dari peristiwa tidak seperti yang diharapkan. Seharusnya, aksi brutal Paddcok yang membunuh lebih 50 orang dan melukai 500 orang disebut sebagai aksi teror, bukan penembakan biasa. Donald Trump seharusnya menyatakan aksi berdarah sebagai tindakan teroris, tetapi tidak ada satu pun pernyataan Trump yang menamakan sebagai teror.

Penegasan bahwa penembakan massal seharusnya disebut atas tragedi Las Vegas diperkuat dengan pernyataan Republika pada paragraf ke-14 yang ditulis bahwa profil Paddock yang bukan Muslim dan bukan berkulit hitam memang sebuah ironi yang memancing keingintahuan publik mengenai motif pelaku. Dinyatakan, "sebab, stereotip yang coba dibangun selama ini teroris adalah Muslim dan bukan orang kulit putih," sebagai penegasan kalimat (diksi) sebelumnya bahwa tidak disebutnya Paddcok sebagai teroris karena dia bukan muslim dan berkulit putih. 
Republika menilai aksi Paddcok tidak disebut teroris oleh Trump melalui narasi Burston saat menilai komentar Trump bahwa, "seorang pria menembakkan senjatanya. Pria bersenjata itu bukan teroris. Itu murni aksi oleh setan," dengan kalimat yang mempertanyakan bahwa, "kesimpulan Burston, setan bukankah teroris. Benarkah?" sebagai cara Republika menegaskan bahwa kejahatan Paddock adalah aksi teroris. Dalam mendefinisikan masalah ini, Republika menampilkan pandangan orang lain, yakni Bardley Burston (kolumnis dan editor senior harian Haaretz, yang terbit di Israel) dan opini kolumnis ternama Thomas L. Freidman di New York Times. Republika dalam menyikapi persoalan ini hati-hati dengan cara mengonstruksikan pendapat pakar di media massa internasional yang kemudian dikuatkan dengan pandangan redaksi Republika.

Melalui dua pandangan kolumnis dari media massa internasional, Republika menempatkannya sebagai sumber informasi yang secara tegas menyebut tindakan Paddock adalah aksi teroris. Penyebutan Republika merupakan bentuk perlawanan atas penolakan sikap Trump yang menamai aksi berdarah itu sebagai pelaku penembakan. Republika mendefinisikan masalah bukan pada fenomena tragedi kebrutalan Paddock, tetapi meletakkan masalah pada sikap penguasa negara adidaya terhadap kekerasan (teror) yang dilakukan warganya.

Redaksi Republika memperkuat argumentasi penjulukan tindakan terorisme Paddock dengan mengutip tulisan Tracy Clayton di Huffingtonpost, Selasa (3/10/ 2017) yang berisi sindiran atas sikap Tump yang tidak mau menjuluki teroris atas tindakan Paddock. Pada paragraf ke-12, Republika menuliskan kicauan Tracy, Berita: "Seseorang telah melakukan aksi kekerasan." Aku: “Tuhanku, aku berharap dia bukan orang kulit hitam." Berita: "penembak ternyata pelaku tunggal." Aku: "Oh, jadi mereka berkulit putih." Pilihan selebtwit yang ditampilkan Republika mendukung sikapnya yang dituangkan dalam judul Tajuk "Ironi Paddock, Ironi Trump" bahwa yang seharusnya mendapatkan julukan teroris adalah identitasnya muslim dan berkulit hitam, namun pelakunya (Paddock) ternyata berkulit hitam dan non muslim yang membuat Trump tidak menyebutnya teroris.

\section{Diagnosa Causes}

Redaksi Republika mendudukkan subyek (who) sebagai masalah dengan menampilkan pandangan Bradley Burston dalam opininya di harian Haaretzdi Israel yang mempersoalkan tidak munculnya pernyataan teroris dari presiden Amerika Serikat Donald Trump atas penembakan di Las Vegas. Narasi yang dipilih oleh Republika dalam menempatkan tidak disebutnya tindakan teroris dalam kasus penembakan massal sebagai masalah berupa kutipan pernyataan Buston pada paragraf yaitu, "Ketika aksi teroris itu dilakukan oleh pemilik senjata warga Amerika berkulit putih, Trump tak mengeluarkan sepatah katapun. Dan tak akan." Dalam konteks ini, Republika menempatkan sosok penguasa Amerika Serikat sebagai sumber masalah dalam bersikap yang melindungi warganya dari sebutan teroris. 
Pernyataan diperkuat dengan kalimat berikutnya pada paragraf kedua dengan menjelaskan maksud pernyataan pertama. Bahwa, sepatah kata yang dimaksud Burton adalah pernyataan dari Presiden Amerika Serikat Donald Trump bahwa penembakan massal di Las Vegas itu tidak menyebut kata "teroris" pada pelakunya. Dijelaskan dalam kalimat berikutnya, "Trump memang tak menyematkan istilah teroris kepada Stephen Craig Paddock (64 tabun)," dengan diikuti penjelasan narasi bahwa Paddock yang beristrikan wanita kelahiran Filipina ini hanya disebut sebagai pelaku penembakan, bukan teroris.

Paddock dijelaskan sebagai penyebab utama dari tewasnya puluhan orang yang menyaksikan konser tersebut, tetapi Republika tidak mendudukkan sebagai persoalan utama. Republika memfokuskan pada standar ganda presiden Trump yang menolak menyebut aksi Paddock sebagai tindakan teroris. Berbeda dengan penjulukan aksi lain seperti tragedi Paris Perancis pada November 2015, Trump menyebutnya teroris karena diketahui pelakunya adalah Muslim. Republika mengonstruksikan bahwa masalah utamanya adalah penjulukan aksi kekerasan yang dilakukan oleh seorang "oknum" Muslim langsung dicap teroris oleh Amerika Serikat.

Republika menempatkan Trump sebagai masalah karena tidak mengakui tindakan teroris Paddock didukung dengan fakta yang ditampilkan berupa pandangan Burston yang membandingkan reaksi Trump ketika penembakan terhadap kerumunan massa juga terjadi di Paris, Perancis, November 2015. Selanjutnya Republika menulis bahwa Trump dalam cicitan di Twitter langsung berkomentar, "Kapan Presiden Obama mengeluarkan kata teroris Islam radikal? Dia tidak akan mengatakan itu, kecuali jika dia mau, jadi masalabnya memang tak akan pernah terpecabkan."

\section{Make Moral Judgement}

Redaksi Republika mengungkapkan sikap standar ganda yang dilakukan oleh Trump dalam menyikapi setiap kekerasan yang terkait dengan kepentingan Amerika Serikat. Republika kembali menarasikan gagasan Burston mengenai standar ganda yang mendukung gagasan pada level define problem dan diagnosa cause bahwa penembakan massal yang merupakan tindakan teroris tidak disebut oleh Trump sebagai aksi teroris. Digambarkan oleh Republika bahwa Burston menyebut ada reaksi yang berbeda atas dua kasus yang memiliki kemiripan unsur kekerasan, yakni Paris dan Las Vegas. Republika kemudian mengonstruksikan bahwa, "saat aksi teroris di Paris itu dilakukan oleh seorang Muslim, Trump tanpa tedeng aling-aling mengeluarkan istilah teroris Islam radikal bagi para pelaku," merupakan pernyataan Trump yang tidak dilakukan ketika peristiwa Las Vegas didalangi oleh Paddock yang non-muslim. Penggunaan kata "tedeng aling-aling" sebagai makna dalam bahasa Jawa yang dipilih Republika menggambarkan bahwa Trump secara terang benderang tidak ragu lagi menyebut teroris radikal Islam terhadap kejadian teror di Paris karena identitas pelakunya diketahui muslim. 
Republika memperkuat argumentasi standar ganda Trump tersebut dengan mengontruksikan pandangan kolumnis ternama Thomas L. Friedman yang menulis opini di New York Times berjudul "Andaikan Stephen Paddock adalah seorang Muslim" untuk menggambarkan reaksi Trump. Republika mengutip tulisan Friedman yang menyatakan jika pelaku pembantaian di Las Vegas itu seorang Muslim, Trum tentu akan berkicau di Twitter setiap jam. Sebagaimana reaksinya ketika serangan teror di Eropa dilakukan seorang Muslim. Republika menekankan kritikan Friedman dengan kalimat, "sebuab ironi bagi Trump," sebagai diksi atas sikap kontradiktif Trump ketika menyangkut pelakunya Muslim atau non-Muslim.

Pesan moral yang ingin disampaikan oleh Republika adalah bahwa persoalan penembakan massal jelas dilakukan oleh seseseorang yang layak disebut teroris. Sedangkan ketidakmauan Trump menyebut teroris karena stereotip yang terbangun terhadap umat Islam yang layak dijuluki teroris, sedangkan pelaku yang non-muslim dan berkulit putih tidak layak dinamakan teroris. Untuk mendukung argumentasi stereotip buruk ini, Republika menjelaskan pandangan Friedman yang terkenal dengan ulasan-ulasan bernasnya mengandaikan Paddock meneriakkan "Allahu Akbar" saat memberondongkan senjatanya ke kerumunan massa selama 10 menit. Friedman juga mengandaikan Paddock sebagai anggota ISIS atau dia berpose dengan salah satu tangannya memegang Al-Quran dan tangan lainnya menenteng senjata.

Republika memilih pandangan Burston dan Friedman untuk mengokohkan pandangan redaksi dalam mengungkapkan makna bahwa standar ganda yang ditampilkan Trump harus diluruskan. Sebab, stereotip Trump terhadap Islam yang diidentikkan dengan teroris dapat diwakili melalui tulisan Friedman yang mengandaikan dengan simbol-simbol kata-kata "Allahu Akbar", "ISIS", dan "Alquran" sebagaimana digambarkan pada paragraf ke-10.

\section{Treatment Recommendation}

Redaksi Republika menawarkan sebuah penyelesaian masalah agar terdapat keadilan dalam memberikan identitas pelaku kejahatan dengan standar yang jelas, bukan sekadar standar ganda gaya Presiden Trump. Argumentasi atas penyebutan teroris dalam aksi tersebut dikonstruksikan oleh Republika melalui kritik oleh dua kolumnis yang ditampilkan, baik Burston maupun Friedman yang sama-sama secara tegas menyebut aksi biadab Paddock dengan tindakan teroris. Republika menegaskan pandangannya melalui pernyataan, "sebagaimana Burston, Friedman mengulas adanya standar ganda reaksi Trump terhadap aksi teroris," sebagai pesan atas sikap tidak adil Trump yang tidak boleh dilakukan. Maka pada bagian akhir paragraf ke-15, Republika menawarkan sebuah wacana yang adil dengan mengutip definisi terorisme untuk mengidentifikasi aksi Paddock sebagai tindakan teroris.

Tawaran definisi Republika dilandasi oleh suatu kenyataan bahwa sampai Tajuk Republika dipublikasikan kepada khalayak pada tanggal 5 Oktober 2012 karena alasan yang mendorong Paddock menjagal kerumunan penonton yang 
sedang menikmati riuhnya konser itu masih didalami pihak berwajib. Republika pada paragraf ke-13 mengonstruksikan ada banyak kemungkinan yang melatarinya, mulai dari stres utang judi, dendam kasino, penyakit mental, hingga politik dalam negeri AS.

Republika menulis bahwa terorisme adalah aksi yang melibatkan penggunaan atau upaya sabotase, pemaksaan, atau kekerasan yang mengakibatkan kematian populasi secara umum. Pada kata penutupnya, Republika mengajak pembaca menyetujui tindakan Paddock teroris dengan kalimat tanya, "apakah aksi biadab Paddock sudah memenubi kriteria itu," sebagai rekomendasi retoris sehingga bisa dijawab dengan kata "sudah memenuhi" kriteria teroris. Pertanyaan ini sebenarnya menegaskan narasi yang dipilih untuk menolak diskriminasi penjulukan yang dilakukan Trump. Pemilihan pandangan Burston dan Friedman memberikan pesan bahwa Republika menyetujui pandangan dua kolumnis itu dalam menilai Trump yang arogan menolak kata teroris terhadap aksi warganya yang non muslim dan berkulit putih.

Berdasarkan data-data yang dihasilkan dari opini tajuk Republika dengan menggunakan analisis framing model Entman, dapat digambarkan dalam tabel sebagai berikut:

Tabel 1. Hasil Penelitian Analisis Framing Model Entman

\begin{tabular}{|c|c|c|}
\hline Langkah & Elemen & Hasil Dimensi Yang Diteliti \\
\hline 1 & $\begin{array}{l}\text { Define } \\
\text { problems }\end{array}$ & $\begin{array}{c}\text { Republika melihat peristiwa penembakan massal Las } \\
\text { Vegas yang dilakukan Paddock sebagai aksi teroris, } \\
\text { bukan penembakan biasa. }\end{array}$ \\
\hline 2 & $\begin{array}{c}\text { Diganosa } \\
\text { causes }\end{array}$ & $\begin{array}{l}\text { Republika menilai Presiden AS Donald Trump sebagai } \\
\text { masalah karena menolak menyebut aksi berdarah Las } \\
\text { Vegas dengan identitas teroris. }\end{array}$ \\
\hline 3 & $\begin{array}{l}\text { Make moral } \\
\text { judgement }\end{array}$ & $\begin{array}{l}\text { Republika menilai Presiden Trump menggunakan standar } \\
\text { ganda dalam menyikapi aksi kekerasan. Jika identitas } \\
\text { pelakunya muslim dituding teroris, sedangkan } \\
\text { pembunuhan massal Paddock sebagai "setan sejati” dan } \\
\text { menghindari kata teroris. }\end{array}$ \\
\hline 4 & $\begin{array}{l}\text { Treatment } \\
\text { recommendation }\end{array}$ & $\begin{array}{l}\text { Republika menawarkan definisi terorisme sebagai aksi } \\
\text { yang melibatkan penggunaan atau upaya sabotase, } \\
\text { pemaksaan, atau kekerasan yang mengakibatkan kematian } \\
\text { populasi secara umum. }\end{array}$ \\
\hline
\end{tabular}

Sumber: Diolah berdasarkan hasil penelitian

Makna teks dalam tajuk pada empat level (define problem, diagnosa cause, make moral judgement, dan treatment recommendation) dengan studi literatur dan teori yang memadai untuk menjelaskan realitas makna dalam teks tajuk berjudul "Ironi Paddock, Ironi Trump" yang diteliti. Studi literatur yang digunakan adalah jurnal, buku, dan media massa yang terkait dengan fenomena seputar penembakan Las Vegas. Sedangkan teori yang digunakan untuk menginterpretasikan makna dibalik teks Tajuk Republika adalah melalui Teori Konstruksi Sosial atas Realitas yang 
dikemukakan Peter L. Berger dan Thomas Luckman. Tesis utama dari Berger (Nurhadi, 2015: 78) adalah manusia dan masyarakat adalah produk yang dialektis, dinamis, dan plural secara terus-menerus. Bagi Berger, realitas itu tidak dibentuk secara ilmiah tidak juga sesuatu yang diturunkan Tuhan, tetapi ia dibentuk dan direkonstruksi. Dengan pemahaman seperti itu, realitas berwajah ganda. Setiap orang bisa mempunyai konstruksi yang berbeda-beda atas suatu realitas. Selain plural, konstruksi sosial juga bersifat dinamis. Sebagai hasil konstruksi sosial maka realitas dapat merupakan realitas subyektif dan realitas objektif. Realitas subjektif, menyangkut makna, interpretasi, dan hasil relasi antarindividu dengan objek. Sedangkan realitas objektif, merupakan sesuatu yang dialami, bersifat eksternal, berada di luar atau dalam istilah Berger, tidak dapat kita tiadakan dengan anganangan.

Berdasarkan teori ini, Republika sebagai institusi sosial media massa memiliki perspektif tersendiri ketika melihat realitas kasus penembakan massa Paddock. Sebab, institusi media dikendalikan oleh individu-individu yang memiliki pemaknaan tertentu atas realitas. Dalam hal ini, tajuk "Ironi Paddock, Ironi Trump" merupakan pandangan subjektif redaksi dalam memaknai kejadian tersebut. Ideologi Islam yang dianut oleh awak redaksi ikut mempengaruhi cara pandang dalam menyematkan aksi Paddock sebagai aksi teror. Hal ini nampak jelas dari pemilihan Tajuk Republika pada Edisi 5 Oktober 2017 yang mengangkat kasus Paddock dengan didukung kekuatan pemberitaan dan opini masyarakat yang dipilih membahas tragedi berdarah. Konstruksi realitas yang dilakukan oleh Republika juga nampak dari pemakaian kata dan kalimat dalam tajuk yang mendukung gagasan (pendapat) bahwa aksi Paddock adalah teroris dan menjadi masalah besar (ironi) karena Presiden Trump tidak memakai kata teroris dalam memaknai pembunuhan massal yang dilakukan Paddock. Dengan demikian, analisis framing atas Tajuk Republika sejalan dengan teori konstruksi sosial atas realitasnya Berger dan Lucman. Dengan mengafirmasi dengan teori konstruksi sosial atas realitas, maka hasil penelitian dan pembahasan framing Entman atas Tajuk Republika yang diteliti dapat dianalisis dengan mengungkapkan pada empat dimensi penting sebagai berikut.

Pertama, pendefinisian masalah (define problem) atas penembakan massa yang dilakukan Paddock sebagai aksi teror merupakan cara Republika untuk menempatkan makna kekerasan secara proporsional. Penegasan ini sesuai dengan pandangan ideologi Islam yang dianut Republika sehingga upaya meluruskan makna atas realitas dilakukan melalui pandangan redaksi, yakni tajuk yang merupakan sikap resmi redaksi. Pendefinisian aksi Las Vegas sebagai aksi teror didukung dengan opini masyarakat yang dipilih dan ditampilkan oleh Republika pada Edisi 5 Oktober 2017. Affan (2017: 6) menyatakan secara tegas dalam opini Republika berjudul “Teror Zonder Teroris" bahwa penembakan brutal yang dilakukan Paddock adalah aksi teror. 
Affan mengkritik tidak adanya media populer di AS dan pernyataan resmi pemerintahan Trump yang menyebut Paddock sebagai teroris. Affan menegaskan bahwa dalam perdebatan politik di sebuah negara yang terpolarisasi, seperti AS, kata "terorisme" merupakan senjata yang dipegang secara bebas, terutama saat pelakunya beragama Islam. Label "terorisme" sangat merendahkan dan membawa begitu banyak konsekuensi di dalamnya. Label "teroris" di AS tak ubahnya cap "komunis" di Indonesia yang menyebabkan seseorang dapat kehilangan hak-hak dasarnya sebagai manusia. Setiap terjadi aksi terorisme, minoritas Muslim di AS menjadi komunitas pertama yang diliputi kecemasan. Muslim Amerika berdoa agar pelakunya bukan seorang Muslim, atau membawa simbol-simbol Islam. Sebab, hal demikian makin meningkatkan stereotipesasi Islam dengan terorisme.

Menempatkan teroris atau tidaknya sebuah tindakan Paddock menjadi perdebatan di media massa. Auliani (2017) dalam reportase Kompas.com (05/10/2017) menjelaskan bahwa sampai Kamis (5/10/2017), pemerintah dan otoritas keamanan Amerika Serikat tidak menyebut Stephen Paddock-pelaku penembakan yang menewaskan 58 orang dan melukai ratusan orang di Las Vegas, Clark County, Nevada, pada Minggu (1/10/2017)—sebagai teroris. Ketiadaan motif terkait politik dan atau keterkaitan Paddock dengan organisasi tertentu, merupakan dalih otoritas Amerika Serikat tak menyebut pelaku penembakan terburuk kedua dalam sejarah Amerika Serikat itu sebagai teroris ataupun aksinya sebagai terorisme.Ketidakjelasan motif Paddock sampai saat ini punya kaitan jelas dengan tidak disebutnya lelaki itu sebagai teroris maupun pelaku terorisme.

Sejumlah kalangan di Amerika Serikat pun mempertanyakan fakta tak munculnya kata teroris dan terorisme dari aksi Paddock itu. Kompas.com dalam laporannya menyebutkan media massa BBC edisi Selasa (3/10/2017), misalnya, menyitir salah satu akun di Twitter yang menyebut, andai Paddock adalah Muslim maka dia hampir pasti sudah disebut teroris dan aksinya langsung dicap sebagai terorisme. Netizen menyebut pula, tulis BBC, andai Paddock adalah muslim, maka label teroris Islamis bakal langsung melekat bahkan tanpa perlu ada bukti dulu.Terlebih lagi, aksi Paddock dianggap sudah memenuhi definisi teroris dan terorisme dalam UU Nevada. Definisi terorisme bisa ditemukan di Angka 1 Nevada Revised Statutes (NRS) 202.4415. NRS merupakan kodifikasi dari semua UU yang masih berlaku di negara bagian Nevada (Auliani, 2017).

Pertanyaan atas tidak munculnya kata teroris dan terorisme dalam kasus Paddock karena makna terorisme sendiri mengalami pergeseran orientasi oleh berbagai kepentingan tertentu. Sebagaimana dinyatakan oleh Paul Wilkonson (dalam Yunanto, 2017: 6-7) bahwa ada lima karakteristik utama dari terorisme, yaitu: 1) suatu tindakan untuk menciptakan iklim ketakutan dan teror; 2) targetnya lebih luas dari korban langsung; 3) menyerang secara random termasuk targettarget simbolis dan masyarakat sipil; 4) dipandang sebagai suatu aksi yang tidak normal karena merusak norma masyarakat; 5) tujuannya adalah mempengaruhi perilaku politik. Namun, dalam perkembangannya, kata Yunanto, pada abad ke- 
20 terjadi perubahan secara masif dalam motivasi yang mendasari terorisme. Terorisme telah menjadi bagian dan ciri dari suatu pergerakan politik dari kelompok ekstrim kanan maupun ekstrim kiri dalam spektrum ideologi negara.

Pemaknaan atas teror, terorisme, dan teroris semakin dinamis karena realitasnya telah sedemikian rupa dikonstruksikan sebagaimana dikemukakan Jainuri (2016: 120-121) yang melihat ada dua macam jenis terorisme, yakni state terrorism dan non-state terrorism. Yang pertama biasanya menjadi instrumen kebijakan suatu rezim penguasa dan negara, sedang yang kedua merupakan bentuk perlawanan terhadap perlakuan politik, sosial, maupun ekonomi yang tidak adil dan represif yang menimpa seseorang atau kelompok orang. Contoh yang lebih umum, yang pertama biasanya mewakili penguasa penjajah, sedang yang kedua perlawanan dari rakyat terjajah. Sebagai sebuah label untuk tindakan kekerasan, istilah ini mencerminkan makna negatif bagi mereka yang dijuluki teroris. Dalam pengertian ini teroris disamakan dengan istilah yang menyakitkan lainnya dalam khazanah bahasa politik, seperti rasis, fasis, atau imperialis.

Dalam dunia politik, istilah terorisme sering kehilangan makna yang sebenarnya dan menjadi bagian dari retorika yang menyakitkan antara politikus yang bertikai. Seseorang atau kelompok yang sedang bertikai biasanya menuduh lawan politiknya dengan melakukan teror, dan apabila tujuan teror ini berhasil, maka mereka tidak ragu untuk melakukan secara berulang tindakan teror terhadap lawan. Akibatnya, "sekali seseorang itu dituduh teroris maka orang yang menuduh dan yang lain merasa memiliki kebebasan untuk enyerang dan menghukumnya dengan tindakan keras dan menyakitkan.”

Berdasarkan realitas pemaknaan teroris yang terkonstruksikan, Republika menyebut tindakan Paddock dengan teroris. Penegasan Republika dikonstruksikan dalam narasi teks Tajuk sebagai makna yang tidak di justifikasi oleh redaksi Republika sendiri. Untuk itu, Republika menampilkan pandangan Burston dan Friedman sebagai kolumnis di dunia yang pandangannya dapat memperkuat sikapnya bahwa tindakan Paddock terkategori aksi teroris. Hal ini sekaligus digunakan Republika untuk melawan sikap Presiden Trump yang menilai sebagai " pelaku penembakan", "orang gila", atau "setan sejati" dan tidak mau menyebutnya dengan kata-kata teroris.

Strategi framing Republika yang mengakomodasi pendapat yang serupa memberikan kesan bahwa Republika tetap berhati-hati dalam memaknai peristiwa Las Vegas. Dalam hal ini, Republika menggunakan bahasa retoris untuk menawarkan pendapatnya kepada khalayak sebagai institusi sosial yang mewakili pandangan sebagian masyarakat.

Kedua, peletakan sumber masalah (diagnosa cause) atas kasus Paddock, dikonstruksikan Republika dengan menempatkan realitas standar ganda presiden Trump sebagai penguasa negara Amerika Serikat yang memiliki kuasa untuk menjuluki siapa saja yang bertindak kekerasan; apakah dijuluki teroris atau bukan teroris. 
Fenomena penjulukan teroris yang secara sepihak dilakukan negara adidaya semacam Amerika Serikat mendapatkan kritik keras dari ilmuwan komunikasi. Mulyana (2014: 262) menyatakan bahwa sebenarnya tidaklah mengejutkan bila Amerika Serikat sebagai “sang Tuan” dunia dan banyak negara Barat lainnya lewat media memaksakan definisinya sendiri mengenai tindakan apa saja yang termasuk teroris dan siapa yang dapat dijuluki teroris. Sayangnya, karena begitu gencar dipromosikan media massa, pemaknaan sepihak itu tanpa sadar diterima orang, kelompok, bangsa, khususnya mereka yang mengekor dan bersimpati kepada Amerika. Definisi Amerika mengenai segala hal menjadi semacam sumber "konstruksi sosial" (lebih tepatnya propaganda) yang tidak pernah kita persoalkan lagi.

Pandangan Mulyana diperkuat pendapat yang menyatakan karena teroris juga dapat dilakukan oleh pemerintah atau negara, maka Amerika Serikat yang menebar ketakutan di Irak, Afganistan, Pakistan, Iran, dan bahkan di seluruh belahan bumi dengan semboyan tongkat dan tomat, hakekatnya adalah negara teroris. Begitu juga Israel yang membuat rasa takut dan menjajah bangsa Palestina, membuat takut bangsa Libanon dan bahkan negara-negara Timur Tengah, dan ternyata Israel adalah negara bagian terakhir dari Amerika Serikat, maka sesungguhnya Israel adalah negara teroris. Jadi Amerika Serikat dan Israel adalah negara Teroris (Sila, dkk, 2015:xxvii).

Menurut Yunanto, dkk (2017: 11) kegiatan terorisme mempunyai tujuan untuk membuat orang lain merasakan ketakutan sehingga dengan demikian dapat menarik perhatian orang, kelompok atau suatu bangsa. Biasanya perbuatan teror digunakan apabila tidak ada jalan lain yang dapat ditempuh untuk melaksanakan kehendakanya.

Ketiga, persepsi negatif negara-negara Barat, terutama Amerika Serikat karena didorong cara pandang yang stereotip. Penamaan berbagai kekerasan di belahan dunia yang diidentikkan dengan teroris jika pelakunya muslim memosisikan pandangan yang tidak adil pihak Barat kepada umat Islam.

Fenomena kebencian Barat terhadap ajaran Islam dituangkan melalui berbagai produk komunikasi massa, baik media massa (cetak, elektronik, dan online) maupun media lainnya dalam menggambarkan kebencian. Sikap Trump yang tidak mau menyebut aksi sadis Paddock sebagai aksi terorisme semakin meyakinkan mengenai standar ganda Amerika yang stereotip terhadap Islam dan umat Islam. Dalam hal ini, Republika mendudukkan agar masyarakat memiliki standar yang jelas dalam menilai sebuah tindak kekerasan sehingga yang muncul bukan bentuk-bentuk stigma negatif terhadap Islam.

Fenomena stereotip yang diciptakan Barat digambarkan Mulyana (dalam Wazis, 2015: 264-266) bahwa menyebut media Barat, terutama media Amerika, sering memaknai Islam sebagai agama primitif yang membenarkan perbudakan, poligami, harem-harem, penindasan terhadap wanita, kekerasan dan terorisme. Poligami, yang merupakan salah satu solusi untuk mengatasi kaum muslim, dan 
berada di wilayah feri-feri ajaran Islam, sering dianggap suatu ajaran yang utama. Khalayak media pun teracuni oleh wacana menyesatkan ini. Di Amerika stereotipstereotip negatif tentang Islam dan kaum muslim khususnya tentang kekerasan, telah beberapa dekade disiarkan lewat film-film lebar seperti Under Siege, Harem, Delta Force, True Lies, dan Executive Decision. Delta Force menggambarkan orangorang Islam shaleh yang diasosiasikan dengan teroris-teroris yang menyerang wilayah Amerika. Dilukiskan, tempat utama pelaku utama (Abu Ladin) adalah daerah pinggiran Kota Detroit yang komunitas muslimnya dalam kehidupan nyata memang padat. Pelaku utama itu diringkus ketika ia sedang shalat.

Mulyana menjelaskan mengenai penghinaan media massa Barat terhadap Nabi Muhammad. Koran Denmark Jyllands Posten pada edisi 30 September 2005 memuat 12 kartun yang sebagiannya menghina Islam dan Nabi Muhammad SAW. Dalam salah satu kartun itu Nabi Muhammad SAW dilukiskan sebagai seorang Arab Badui yang membawa pedang, didampingi dua perempuan bercadar hitam di kiri dan kanannya. Gambar ini memberikan pesan bahwa Islam disebarkan oleh Nabi Muhammad SAW lewat terorisme. Apalagi, gambar-gambar itu disiarkan pada bulan September sehingga orang mengasosiasikannya dengan peristiwa WTC 11 September. Satu kartun lainnya menggambarkan wajah Nabi Muhammad SAW yang memakai surban di kepalanya, namun sebuah dinamit yang sedang menyala menyembul dari bilik surban tersebut. Atas nama kebebasan pers, kartun-kartun itu kemudian diterbitkan lagi oleh koran-koran di Swedia, Belanda, Perancis, Spanyol, Italia, Selandia Baru dan Australia.

Barat, kata Mulyana, rupanya tidak pernah mau belajar dari kesalahan mereka. Terakhir, dunia Islam sekali lagi dibuat gempar dan berang oleh sebuah film dokumenter Fitna yang dibuat oleh Geert Wilder. Lagi, ditayangkan potongan-potongan film, termasuk runtuhnya menara kembar WTC di New York, yang dirangkai untuk memberikan kesan bahwa kaum muslim itu haus darah. Di antara adegan-adegan film tersebut, Wilders juga mengutip ayat-ayat Qur'an yang keluar dari konteksnya. Dalam film tersebut juga dimunculkan lagi kartun-kartun yang menggambarkan wajah Nabi Muhammad SAW dengan sorban di kepalanya dan bom yang siap meledak. Ini benar-benar penghinaan terhadap Islam dan Nabi Muhammad SAW. Wilders benar-benar tidak punya sensitivitas bahwa kaum Muslim begitu menghormati Nabi mereka. Mulyana menegaskan, "mengherankan bahwa zaman global yang menuntut toleransi antarbangsa seperti sekarang masib ada orang dungu seperti itu," untuk menggambarkan realitas yang paradoks ditampilkan Barat dalam memaknai Islam. Kaum muslim tidak 
pernah menghina tuhan-tuhan (atau nabi-nabi) agama lain, karena Qur'an sendiri mengingatkan hal itu.

Stereotip negatif Barat atas Islam dan umat Islam yang dikonstruksikan dalam framing media massa mereka, menurut Machendrawati dan Safei (2001: 256-257), menunjukkan bahwa globalisasi media yang disokong jaringan korporasi modal internasional telah menembus batasan kultural, geografi, dan negara sehingga beragam cara pandang bertemu dalam tingkat yang intensif. Globalisasi media sanggup mengaduk-aduk seluruh tatanan kehidupan manusia. Ia bisa menjadi sarana untuk mencerdaskan manusia, tetapi pada saat yang bersamaan bisa juga dipakai untuk menikam orang lain. Secara faktual, Barat terlampau mendominasi media, sehingga yang terjadi adalah ketimpangan dan ketidakadilan informasi.

Machendrawati dan Safei mengutip pandangan Arismunandar bahwa, terdapat tiga kritik atas dominasi peran media Barat ini, yaitu: 1) media Barat terlalu kuat. Mereka menyusup terlalu luas dan dalam di negara-negara dunia ketiga (negara-negara Islam hampir seluruhnya masuk kategori dunia ketiga); 2) pelayanan berita mereka tidak benar-benar bersifat "internasional". Berita-berita yang disebrakan diseleksi untuk memenuhi sikap, nilai-nilai, dan kepentingan Barat. Realitas digambarkan menurut orientasi Barat; 3) mereka kurang mementingkan akurasi dan objektivitas yang menjadi dasar klaim mereka bagi penghargaan internasional. Lebih-lebih kalau sudah enyangkut berita tentang Islam atau umat Islam.

Keempat, mengenai dimensi treatment recommendation, Republika yang menawarkan definisi terorisme dapat dimaknai agar terdapat kesamaan dalam menilai sebuah realitas terorisme. Pandangan Republika dalam tajuk sejalan dengan tawaran solusi Affan (2017: 6) yang menyatakan bahwa tragedi Las Vegas mestinya menyadarkan dunia untuk bersikap 'fair'. Tak sepatutnya Islam terus dituduh sebagai agama teroris. Setiap kekerasan yang menimbulkan teror luas, baik dilakukan atas motif ideologis tertentu maupun tidak, berlatar belakang apa pun, adalah bentuk terorisme yang pelakunya pantas disebut "teroris". Setiap aksi terorisme adalah musuh bersama yang harus dilawan bersama. Terorisme tidak dapat dilekatkan pada identitas atau ideologi tertentu. Semua manusia berpotensi melakukan kejahatan dan teror. Affan menyatakan, "pada saat melakukan teror, maka pantas ia disebut teroris." Karena realitas makna teroris telah mengalami konstruksi yang dinamis, maka pandangan Affan menegaskan agar siapapun tidak ragu menjuluki tindak kekerasan pembunuhan ketika dimaknai dengan kata teroris yang tidak lagi bersifat tunggal. 
Yunanto, dkk (2017: 11) menyatakan terorisme umumnya digunakan sebagai senjata psikologis untuk menciptakan suasana panik, tidak menentu serta menciptakan ketidakpercayaan masyarakat terhadap ketidakmampuan pemerintah dan memaksa masyarakat atau kelompok tertentu untuk menaati kehendak pelaku teror. Terorisme tidak ditujukan langsung kepada lawan, tetapi perbuatan teror justru dilakukan dimana saja dan terhadap siapa saja. Dan, yang lebih utama, maksud yang ingin disampaikan oleh pelaku teror adalah agar perbuatan teror tersebut mendapatkan perhatian yang khusus atau dapat dikatakan lebih sebagai psy-war.

Houwling (dalam Sembiring, 2011: 3-5) mengatakan bahwa teror adalah digunakannya kekerasan sebagai alat komunikasi antara pelaku kejahatan dengan sasaran (target) di muka umum. Seperti halnya dengan definisi terorisme, Sembiring juga mengutip pendapat Eqbal Ahmad yang membagi terorisme ke dalam lima tipe, yaitu terorisme negara, terorisme religius, terorisme kriminal, terorisme politik, dan terorisme oposisional.

Sikap Trump yang tidak menyebut aksi Paddock sebagai teroris dan menjuluki Paddock dengan sebutan "orang yang sakit, orang yang gila" atau "setan sejati" (Republika, 2017: 6) sebenarnya juga menunjukkan bahwa sebagian fenomena sosial masyarakat Amerika Serikat sedang sakit dan diantaranya berpotensi melakukan aksi teror. Sebagaimana dinyatakan Nu'ad (2017: 6) dengan mengutip tesis Durkheim bahwa di tengah kedigdayaan Barat dengan segala peradabannya terdapat penyakit psikologis sosial yang teramat akut: frustrasi, dekadensi moral, gangguan psikis, dan seterusnya yang berujung pada praktik bunuh diri dan pembunuhan brutal. Menurut data American Psychiatric Association (APA), 1 persen populasi penduduk AS menderita skizofrenia. Sebuah gangguan jiwa psikotik paling lazim dengan ciri hilangnya perasaan afektif atau respons emosional dan menarik diri dari hubungan antarpribadi.

Nu'ad mengungkapkan fakta bahwa tragedi penembakan di negara bagian AS sering kali terjadi, diantaranya pada Desember 2016, 53 orang tewas akibat penembakan membabi buta di sebuah kelab malam gay. Sebelumnya, pada tahun 2012, tragedi penembakan brutal yang diarahkan ke masyarakat sipil tak berdosa terjadi saat pemutaran film perdana (premier) film Batman: The Dark Night Rises di bioskop Century 16 Aurora, Colorado, AS. Gangguan jiwa skizofrenia dalam masyarakat modern merupakan gangguan jiwa yang akut yang dapat dialami manusia sejak muda dan dapat berlanjut menjadi kronis dan lebih gawat ketika diaktualisasi ke tindakan kriminalitas atau pembunuhan. Karena menyangkut perubahan pada segi fisik, psikologis, dan sosial-budaya. Untuk memperkuat contoh Nu'ad tersebut, kasus di AS berupa pelajar yang melakukan penembakan terhadap kawan-kawannya dan guru-gurunya di sekolah, seperti pernah terjadi di Kota Newton, Negara Bagian Connecticut di Sekolah Dasar Sandy Hook pada 14 Desember 2012, yang menewaskan 28 orang, termasuk 14 anak SD bisa menjadi fenomena yang teror yang sewaktu-waktu bisa terjadi di negara adidaya itu. 
Mengutip Kaplan, Nu'ad menjelaskan bahwa skizofrenia mencakup gangguan pada perilaku, pikiran, emosi, dan persepsi. Ia adalah gangguan psikotik yang kronik, pada orang yang mengalami tidak dapat menilai realitas dengan baik dan pemahaman buruk. Nu'ad mengkhawatirkan bahwa di tengah budaya berubah seperti ini, bukan hanya di AS, namun melanda secara global dalam bentuk budaya kapitalisme global, barangkali penyakit serupa juga dialami generasi muda di Indonesia. Faktornya bermacam-macam, mulai dari tekanan psikis akibat tak tahan menjalani hidup, tak kuasa menghadapi perubahan dan modernitas, sementara agama yang menjadi fondasi utamanya di zaman sekarang ini mulai luntur atau bahkan kosong melompong.

Tawaran Republika dengan penyebutan yang jelas mengenai identitas teroris akan memudahkan para penentu kebijakan dalam penanganan tindak pidana terorisme secara profesional dan proporsional. Dalam konteks ini, Tajuk media massa Republika, dengan mengikuti pendapat Nurudin (2014: 102-103) tajuk rencana yang berusaha menjelaskan suatu peristiwa yang terjadi, meramalkan dan menunjukkan mana yang baik dan mana yang jelas. Ketika media massa dengan informasi dan analisisnya memberikan ilmu pengetahuan pada masyarakat, secara tidak langsung media sedang memfungsikan dirinya sebagai seorang pendidik. Dengan kata lain, apa yang disajikannya mengandung unsur pendidikan. Media massa saat itu sedang mendidik masyarakat.

\section{PENUTUP}

Berdasarkan hasil dan pembahasan penelitian dapat disimpulkan beberapa hal penting. Pertama, Republika menunjukan bahwa kejadian penembakan massal yang dilakukan Paddock sebagai bagian dari aksi yang tergolong teroris. Kedua, Republika menilai bahwa Presiden Donald Trump telah melakukan kekeliruan dalam menanggapi peristiwa penembakan Las Vegas tidak sebagai aksi teroris dan hanya mengatakan sebagai aksi penembakan biasa. Ketiga, Republika menyatakan bahwa Presiden Donald Trump telah memperkuat stereotip bahwa setiap aksi kekerasan identik dengan teroris yang dilakukan seorang muslim. Keempat, Republika memahami terorisme sebagai aksi sabotase, pemaksaan, atau kekerasan sampai menimbulkan kematian.

Hasil penelitian ini dapat dimanfaatkan sebagai materi dakwah Islam dalam menyikapi negara adidaya (Barat) yang memiliki stereotip negatif ketika berbicara ajaran Islam dan umat Islam. Penelitian juga bisa dikembangkan tidak hanya pada koran Republika, tetapi bisa diamati dari versi Republika Online-nya (www.republika.co.id). Dapat pula dibandingkan dengan objek media Islam lainnya yang membicarakan isu-isu global. Dengan menggunakan perspektif kritis, untuk mengungkap realitas media dibalik konstruksi teks yang diproduksi media massa Islam. 


\section{DAFTAR PUSTAKA}

Abrar, A.N. (2015). Tatakelola Jurnalisme Politik. Yogyakarta: Gajah Mada University Press.

Affan, M. (2017, 5 Oktober). Opini:Teror Zonder Teroris. Surat Kabar Republika, 6. Agustian, J.F. (2015). ISIS dan Terorisme dalam Wajah Media Online Indonesia, dalam Proceeding International Post- Graduate Conference 2015 Universitas Airlangga, (4474). Surabaya: Program Studi S2 Media dan Komunikasi Universitas Airlangga.

Auliani, P.A. (2017). Mengapa AS Tak Sebut Penembak di Las Vegas Sebagai Teroris?, diakses $06 \quad$ Oktober 2017, dari http:/ /internasional.kompas.com/read/2017/10/05/22325461/mengapaas-tak-sebut-penembak-di-las-vegas-sebagai-teroris.

Badara, A. (2014). Analisis Wacana: Teori, Metode, dan Penerapannya pada Wacana Media. Jakarta: Kencana Prenada Media Group.

Eriyanto. (2009). Analisis Framing: Konstruksi, Ideologi, dan Politik Media. Yogyakarta: LKiS.

Fakhruroji, M. (2017). Dakwah di Era Media Baru: Teori dan Aktivisme Dakwah di Internet. Bandung: Simbiosa Rekatama Media.

Jainuri, A. (2016). Radikalisme dan Terorisme: Akar Ideologi dan Tuntutan Aksi. Malang: Instran Publishing.

Kompas. (2017, 5 Oktober). Tajuk Rencana. Surat Kabar Kompas, 6.

Kriyantono, R. (2012). Teknik Praktis Riset Komunikasi. Jakarta. Kencana Prenada Media Group.

Machendrawaty, N., Safei, A.A. (2001). Pengembangan Masyarakat Islam: Dari Ideologi, Strategi Sampai Tradisi. Bandung: Rosdakarya.

Mubarok. (2012). Stigmatisasi Pemberitaan Terorisme di Media Massa, diakses03 Oktober 2017, dari ejournal.undip.ac.id/index.php/interaksi/article/view/4443/4053.

Mulyana, D. (2008). Komunikasi Massa: Kontroversi, Teori, dan Aplikasi. Bandung: Widya Padjadajaran.

Mulyana, D. (2014). Komunikasi Politik, Politik Komunikasi. Bandung: Remaja Rosdakarya.

Nurhadi, Z.F. (2015). Teori-Teori Komunikasi: Teori Komunikasi dalam Perspektif Penelitian Kualitatif. Bogor: Ghalia Indonesia.

Pujileksono, S. (2015). Metode Penelitian Komunikasi Kualitatif . Malang: Instrans Publisihing.

Republika. (2017, 5 Oktober). Tajuk:Ironi Paddock, Ironi Trump. Surat Kabar Republika, 6.

Rolnicki, T.E., Tate, C.D., Taylor, S.A. (2015). Pengantar Dasar Jurnalisme. Jakarta: Prenadamedia Group.

Sembiring, J. (2011). Terorisme, Sebuah Pemahaman Masyarakat. Bandung: Komunika Jaya Teknik. 
Sila, M.A., dkk. (2015). Profil Keagamaan Terpidana Terorisme di Indonesia. Jakarta: Badan Litbang dan Diklat Puslitbang Kehidupan KeagamaanKementerian Agama RI.

Subagyo, P.A. (2016). Representasi Frame dalam Latar Belakang Wacana Tajuk tentang Terorisme, diakses 03 Oktober 2017, dari https://journal.uny.ac.id/index.php/litera/article/viewFile/9777/pdf.

Sukarno, A.W. (2011). Dilema Peliputan Terorisme dan Pergeseran Pola Framing Berita Terorisme di Media Massa dalam Jurnal Ilmu Sosial dan Ilmu Politik, 14 (03), 333-348.

Wazis, K. (2015). Konstruksi Kebebasan Media Massa Barat sebagai Budaya Populer: Analisa terhadap Berita dan Karikatur Nabi SAW di Majalah Charlie Hebdo, diakses 03 Oktober 2017, dari http://ejournal.iainjember.ac.id/index.php/aladalah/article/view/326/318.

Yunanto, S., Angel, D., Indah., N. (2017). Ancaman dan Strategi Penanggulangan Terorisme di Dunia dan Indonesia. Jakarta: Institut for Peace and Security Studies (IPSS).

Zakiyah. (2015). Agama Dalam Konstruksi Media Massa: Studi Terhadap Framing Kompas dan Republika pada Berita Terorisme dalam Analisa Journal of Social Science and Religion, 22 (01), 83-96. 